\title{
Integrating Social Entrepreneurship into Higher Education in the New Era
}

\author{
Liqing Li \\ Guangdong-Hong Kong-Macao Greater Bay Area Capital \\ Markets and Auditing Research Institute \\ Guangdong University of Finance and Economics \\ Guangzhou, Guangdong, 501320, China
}

\author{
Feng Yuan \\ China Public Welfare Entrepreneurship Research Center \\ Hunan University \\ Changsha, Hunan, 410000, China
}

\begin{abstract}
This paper studied the necessity and the way of integrating social entrepreneurship into higher education in the New Era using the method of progressive layer by layer. Higher education in China in the new era needs to cultivate college students with social entrepreneurship. Social entrepreneurship can reshape the social morality of college students, promote the innovative thinking of college students in the new era, and cultivate their consciousness of "sustainable development economy". The measures to cultivate college students' social entrepreneurship include setting up research platforms related to social innovation and social enterprises, constructing curriculum teaching system of social enterprises and social entrepreneurship education, and establishing a practical teaching system for college students to set up various kinds of social enterprises.
\end{abstract}

Keywords-Social Enterprises; Social Entrepreneurs; Social Entrepreneurship; Higher Education; College Students

\section{INTRODUCTION}

Higher education is the main way to train talents for modernization and economic development in China. In the past 40 years of reform and opening up, higher education, taking economic development as the main orientation, has trained tens of thousands of excellent entrepreneurs and made important contributions to the economic development in China. However, with the increasingly diversified development of social economy and the frequent occurrence of various social problems, the main contradiction in China has changed from the contradiction between the people's growing needs of the material and cultural and backward social production to the contradiction between people's growing needs for a better life and the insufficient imbalance.

The mode of college students' professional training and quality education, which focuses on economic development, is far from adapting to the development of China in the new era. To solve the imbalance and insufficiency in society, we need more entrepreneurs with a sense of social responsibility. Compared with traditional profit-oriented entrepreneurs, social entrepreneurs can adapt to the development of future society better than before if they have a sense of public welfare and a strong sense of social mission. Therefore, it is urgent to strengthen college students' cultivation of social entrepreneurship in higher education.

\section{THE RELATIONSHIP OF SOCIAL ENTERPRISES, SOCIAL ENTREPRENEURS AND SOCIAL ENTREPRENEURSHIP}

The term "social enterprise" first appeared in the 1990s and was introduced to China in the early 21 st century. Generally speaking, the theory and practice of social enterprise are still being explored in the whole world. Many scholars have put forward their own views on the definition of social enterprises. For example, Nyssens (2006) believes that social enterprises are non-profit organizations that introduce market functions. Borzaga (2001) believes that social enterprises are commercial enterprises aiming at social value. Defourny \& Nyssens (2017) define social enterprises as a dual balance of social mission and economic objectives from the indicators of social enterprises. Wang Mingdeng (2010) believes that social enterprises are non-governmental, non-profit and voluntary public welfare. Pan Xiaojuan (2011) believes that social enterprises have the characteristics of operation and public welfare [2]. In short, there are many studies on the definition of social enterprise, but there is no uniform definition. In my opinion, social enterprises refer to profitable enterprises that take into account social benefits. This kind of profitable enterprises do not take profit as the ultimate goal but take solving various social problems and improving public welfare as the ultimate goal. This social goal runs through the development process of enterprises, and will not easily produce drift [3]. Based on the characteristics, social enterprises have typical characteristics of sociality (public welfare), innovation, market orientation and sustainability [4]. As shown in Fig. 1. 


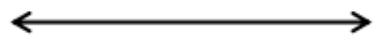

Social Sustainability

Economic Sustainability

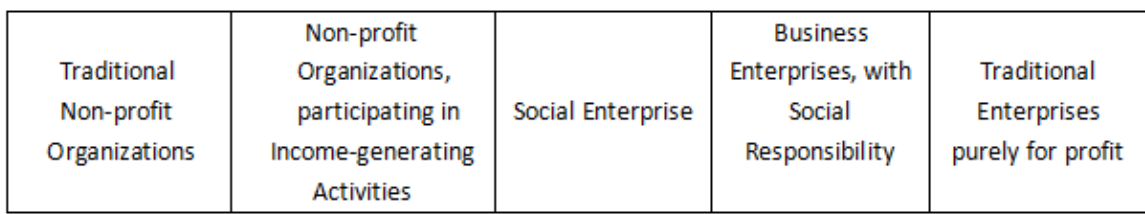

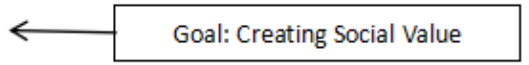

Goal: Creating Economic Value

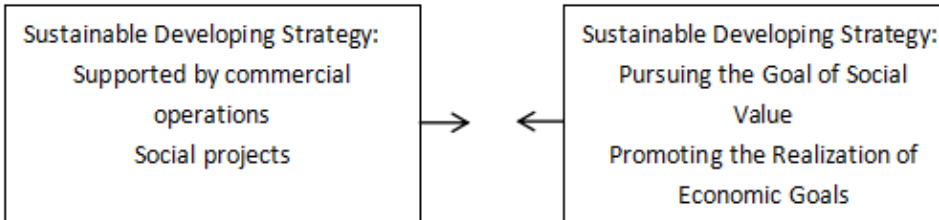

Source: China's social entrepreneurship network and author's comprehensive collation

Fig.1. The spectrum of Social Enterprises

To be exact, the government, non-profit organizations and commercial enterprises can play a role in solving social problems. However, the government aims at political achievements and tends to limit formalism and value quantity rather than quality in solving social problems. Non-profit organizations have no hematopoietic capacity due to they are funded by external donations. Even if some non-profit organizations have a little income, it is insignificant. Therefore, they dare not innovate in the allocation of resources and use old ideas, which leads to the disadvantages of high cost and poor economic sustainability in solving social problems. Commercial enterprises have the ability of hematopoiesis, and some commercial enterprises have the courage to assume part of corporate social responsibility, which is economically sustainable. However, commercial enterprises take profit as their ultimate goal. To assume social responsibility is not the purpose of enterprises, but the means of making profits for enterprises. In solving social problems, commercial enterprises are showier. Instead of really solving this social problem, it may have some effect in the short run. It will inevitably not be recognized by the society and supported by the government in the long run, thus the social sustainability is poor. It can be seen that neither non-profit organizations nor commercial enterprises can really solve the increasingly serious social problems. So, is there an organizational form that can not only avoid the financial limitations of non-profit organizations, but also have the innovative spirit of commercial enterprises? The answer is social enterprise. As shown in Fig. 1, social enterprises effectively integrate the entrepreneurial activities of non-profit organizations with the social responsibility of profit-making enterprises, which is a "mixture" between traditional charitable organizations (non-profit organizations) and commercial enterprises (pure profit enterprises). It seeks a balance between economic sustainability and social sustainability. It is a sublation of traditional commercial enterprises, aiming at promoting social progress by innovative means and safeguarding social fairness and justice. Therefore, some people call it the "fourth sector", which can effectively supplement the failure of the government, non-profit organizations and commercial enterprises in solving social problems [5].

At present, as an important way to construct inclusive social and economic sustainable development, social enterprises are attracting more and more attention from all over the world. In China, social enterprises have covered poverty alleviation, rural revitalization, employment, entrepreneurship, environmental protection, pension, education, entrepreneurship and employment of the mentally handicapped, community services, etc., and these areas are the social problems that need to be solved urgently.

Social entrepreneurs refer to the initiators and executives of social enterprises. Social entrepreneurship refers to the ability to integrate social and economic benefits with the concept of social innovation.

The relationship among social enterprises, social entrepreneurs and social entrepreneurship is that social entrepreneurs create social enterprises through social innovation, and then produce social economy [6].

\section{The Necessity of Cultivating Social ENTREPRENEURSHIP FOR COLLEGE STUDENTS IN THE NEW ERA}

The report of the 19th National Congress of CPC pointed out that the main contradictions of Chinese society in the new 
era have been transformed into the contradictions between the people's growing need for a better life and the unbalanced and inadequate development. The transformation of the main social contradictions means that the focus in the future works of the Party and the government has also shifted, focusing on the shortcomings and strengths and weaknesses. National policies will guide the flow of human resources to places where public services are inadequate. On September 10, 2018, Chinese President Xi Jinping talked about the issue of training people at the National Education Conference. He also stressed the importance of establishing the educational concept of "health first", emphasizing the importance of strengthening students' moral accomplishment and promoting the spirit of work. The great rejuvenation of the Chinese nation and the realization of the Chinese dream require talents who have both ability and virtue, and who can shoulder the banner of national rejuvenation and the heavy responsibility of the social and economic transformation period in the new era. From the perspective of innovation, entrepreneurship and quality education in higher education at home and abroad, the cultivation of social entrepreneurship in higher education can best cultivate college students' sense of social responsibility, personal accountability, and innovation spirit. This is the embodiment of the upgraded version and dimension of innovation and entrepreneurship education.

The significance of cultivating college students' social entrepreneurship lies in the following aspects:

\section{A. It can reshape the social morality of college students in the new era}

The typical representative of social entrepreneurship in the world is Mohamed Yunus, the founder of Bangladesh's Poor Bank. The Poor Bank, founded by Mohamed Yunus, has helped millions of poor entrepreneurs achieve their aspirations to poverty alleviation and entrepreneurship through a business model. The founder, Mohamed Yunus, won the Nobel Peace Prize in 2006. The United Nations awarded Mohamed Yunus the prize, saying: "A lasting peace can only be achieved if a large number of people find a way out of poverty" [7].

From the entrepreneurship history of Mohammed Yunus and other social entrepreneurs, we can see that social entrepreneur are a group with "social feelings". Their original purpose of entrepreneurship is different to the traditional entrepreneurs. The purpose of social entrepreneurship is to solve social problems, while the purpose of traditional entrepreneurs is profit. In the past period, under the guidance of the concept on "only economy, looking at everything from money", there were "exquisite egoist" types of college students in university campuses. The reason why there are such college students is related to the university's lack of social mission and public welfare moral education. The United Nations Educational, Scientific and Cultural Organization (UNESCO) proposed at the Conference on Creativity and Entrepreneurship in Education that entrepreneurs should not only focus on profit-making business entrepreneurs, but also include social entrepreneurs centered on the well-being of poor and marginalized groups. The organization believes that college students should receive social entrepreneurship education and devote themselves to social entrepreneurship. Adam Smith, the father of modern economics, also believes that the "Moral Sentiment" is far more important than "Wealth of Nations". Adam Smith believes that the market does not necessarily promote the progress of social and public interests. We should emphasize the standard of moral values, and be more vigilant against the damage for the greedy nature of capital to social public welfare.

Social entrepreneurs are "socioeconomic" talents on the premise of "public interest". Social entrepreneurship is a kind of good education that combines self-interest and altruism. To cultivate social entrepreneurship of college students in higher education is not only conducive to the development of key skills for college students, but also to the exercise of their leadership ability. The present ideal is more conducive to improving students' ideological and moral character, rebuilding "social fashion" in the future social and economic development, and cultivating college students with "social responsibility, social value and social responsibility".

\section{B. Promoting the innovative thinking of college students in the new era}

Innovation is the process of creating new things and the core of the entrepreneurial process. Schumpeter calls the process of entrepreneurs developing new products and technologies, and continuously eliminating current products and technologies over time as creative destruction. The process of creative destruction improves the current product or technology, so the creative destroyer is called "innovator" or "change promoter". In fact, the process of creative destruction is not limited to the improvement of new products and technologies, but also includes the improvement of new organizations, activities, systems or models [8]. Social enterprise is an organizational innovation. Social entrepreneurs systematically solve social and environmental problems by establishing social enterprises and using new ideas, new models, new products and new services. Social entrepreneurs should not only have the sensitivity of market subjects, but also have a strong sense of social mission. They should be able to find the connection between market demand and social pain points. Social entrepreneurs often have the vision, pattern and behavior of integrating resources across sectors, and the innovative spirit of "new ideas, new dimensions and new markets" that traditional market operators do not possess. This kind of innovation is also called "subversive innovation". In the past, innovative education in Chinese universities was confined to the innovation within traditional commercial enterprises, which led to the decline of large-scale and deep-seated universities to vocational colleges, the disappearance of school hierarchy, and the constant melting of core innovation and entrepreneurship schools. Outside the university, there are Lakeside Universities, so-called business schools, etc. In fact, the practical circles are laughing at the incompetence of the university with their actions. However, the new economic model and social innovation model of the future can not be created by the so-called students in some business schools, or by college students under the higher education system.

It is necessary to change the traditional innovative education and cultivate students' innovative spirit with the subversive innovative spirit of social entrepreneurship, which 
is of great significance to broaden students' vision, innovative dimension and enhance the business pattern. In addition, the innovation of social enterprises also shows that it is a very challenging job to start social enterprises. Ordinary people who do not have enough knowledge can not grasp this innovation, nor can they complete this challenge. According to Liu Zhiyang et al. (2018) survey on the background of social entrepreneurs, more than $90 \%$ of social entrepreneurs are college students [10]. This also shows that in order to cultivate social entrepreneurship, it is necessary to sow the spirit of social entrepreneurship into the thoughts of college students in higher education.

\section{Cultivating college students' consciousness of "sustainable development economy"}

As shown in Fig.1 above, social enterprises overcome the disadvantages of non-profit organizations and traditional business enterprises in sustainable development and achieve a balance between social sustainability and economic sustainability. Traditional non-profit organizations pursue social goals, but lack hematopoietic function, resulting in their lack of economic sustainability in solving social problems. Although some non-profit organizations also have some income-generating activities, these income-generating activities are very limited and can not meet the needs of non-profit organizations in solving social problems. Traditional commercial enterprises pursue profit goals and are economically sustainable. However, they can't get support from the government regardless of social interests, and then they can't achieve social sustainability in the long run. Although many enterprises begin to accept and fulfill corporate social responsibility now, profit is still their main purpose. Addressing social problems is not their main concern. Social enterprises aim at public welfare and address social problems, and operate in the mode of commercial enterprises. They have their own hematopoietic function, so as to truly achieve sustainable development. This sense of sustainable development economy is just what Chinese higher education lacks at present. Therefore, vigorously cultivating college students' social entrepreneurship will help college students to establish a correct concept of sustainable development, jump out of the traditional concept of economic sustainability, and think about sustainable development from a higher perspective.

\section{RESEARCH AND EDUCATION STATUS OF SOCIAL ENTERPRISES AND SOCIAL ENTREPRENEURSHIP AT HOME AND ABROAD}

\section{A. Current situation of research and education on social enterprises and social entrepreneurship in foreign countries}

The education and research of social enterprises and social entrepreneurship have a history of more than 30 years in western countries. So far, more than 30 universities in Britain, the United States, Canada and other countries have carried out educational research on "social enterprises". For example, the Canadian Center for Social Entrepreneurship was set up by Alta University. The American Columbia Business School, the American Social Enterprise Plan, the American Center for Social Progress were set up by Fuku Business School of Duke University. The American Center for Non-profit and Social
Enterprise Management was set up by Seattle University and Stanford University. Corporate-themed research centers, the Institute of Social Enterprises of the United Kingdom was established by Herriot-Watt University, the Cisco Social Entrepreneurship Center of Oxford University and the Social Entrepreneurship Research Center of Northampton University.

Since 2004, Harvard University has enrolled in the first batch of social entrepreneurship (public service entrepreneurship) doctorates, and has offered courses related to "social enterprise" in various colleges of the university. The Said Business School of Oxford University in Britain has clearly defined itself as "the world-class business school, the world-class university, the university that solves the world's problems". Since its establishment more than 20 years ago, the school has trained many outstanding social entrepreneurs for Britain. The University of Northampton in the UK is the first university to take social entrepreneurship education as strategic guidance, and it is also the first university to join the global social entrepreneurship education network. It is the cradle of social entrepreneurship training. As one of the important origins of social entrepreneurship cultivation in the contemporary world, the university has won the British Entrepreneurship University Award for many years, and many leaders have won the Queen's Entrepreneurship Award.

Generally speaking, social entrepreneurship has become an important part of British higher education, and the establishment of social enterprises in the UK also plays an increasingly important role in job creation and economic development. According to the British Council's China Office, in 2018, there were more than 70,000 social enterprises in the UK, more than 2 million employees working in social enterprises, contributing 24 billion pounds to the UK's income [11].

\section{B. Current situation of research and education on social enterprises and social entrepreneurship in China}

Compared with the west, China's universities are still in the initial stage of social entrepreneurship education and research. In 2004, Hunan University took the lead in exploring the systematic industry-university-research of social enterprises in China, and constructed a new model of social enterprise education based on the integration of industry-university-research with "public welfare AIDS + employment + entrepreneurship" based on cluster. This model constructs the whole public welfare entrepreneurship education system from four levels: teaching people to fish (public welfare aided learning) + teaching people to fish (employment) + teaching people to work (entrepreneurship) + teaching people to wisdom (research). It takes social responsibility orientation as the mainline of social enterprise education, and clearly trains outstanding talents with core characteristics of "responsibility, innovation and dedication". It is to achieve win-win economic and social benefits. This educational model has created many first places in China's social enterprise education. For example, China's first social enterprise research institute, "China Public Service Entrepreneurship Research Center", the first higher textbook "Introduction to Public Service Entrepreneurship", the first "University Students Public Service Entrepreneurship" magazine, the first annual meeting of Chinese university 
students public service entrepreneurship, etc., have become the pioneer model of public service entrepreneurship education in China. Hunan University's research on public welfare entrepreneurship has directly or indirectly promoted the development of various innovation and entrepreneurship competitions, such as the Youth League competition of the Communist Youth League Central Committee, the youth entrepreneurship competition of the Youth League, the youth entrepreneurship training camp, the innovation and entrepreneurship competition of the Ministry of Education, and public welfare entrepreneurship, etc.

Under the influence of Hunan University, nearly 100 other universities in China, such as Peking University, Renmin University of China, Fudan University, Tsinghua University, China Youth Political College and China Social Science University, have also carried out various forms of social enterprise exploration and research education. For example, in 2010, Tsinghua University held the "Northern Lights Tsinghua" National College Students Public Welfare Business Time Competition.

In the past five years, a number of profit-making organizations with obvious characteristics of social enterprises have emerged in China, such as non-profit hospitals, schools, scientific research institutions, pension institutions, social service institutions, etc. The number of social enterprises is also growing rapidly, with an annual growth rate of about $30 \%$. According to the statistics of Roland Berger International Management Consulting Company, there are still less than 2,000 social enterprises in China in 2012. By 2018, the number of social enterprises has reached 5,000. Some local governments in China also began to explore, such as: in April 2018, the Chengdu Municipal Government of Sichuan took the lead in developing the certification and cultivation of "social enterprises". In July 2018, the Beijing Municipal Committee formulated the certification standards for "social enterprises". Subsequently, the "social innovation center" was established in Futian District of Shenzhen, Shunde District of Guangdong, etc., to carry out the development of "social enterprises". It is believed that the growth rate of social enterprises will continue to grow under the impetus of the government. If we grow at an average rate of $50 \%$, in less than 10 years, China will become the country with the largest number of social enterprises in the world [13].

Generally speaking, many colleges and universities in China have realized the importance of social entrepreneurship education in higher education, and local governments have also realized the importance of social enterprises in addressing social problems.

However, compared with foreign countries, there is a big gap in the research and education of social enterprises and social entrepreneurship, as well as in the establishment of social enterprises, which need further promotion.

\section{Suggestions on InTEgrating the Cultivation of SOCIAL ENTREPRENEURSHIP INTO COLLEGE STUDENTS' EDUCATION}

Looking at the social entrepreneurship education in universities all over the world, the top ones are Oxford
University, Northampton University, Stanford University, Harvard University and Hunan University. Among them, the social entrepreneurship ecological chain of Northampton University is the most perfect in the world, while Hunan University inherits the experience of social entrepreneurship at home and abroad and established the most perfect social entrepreneurship industry-university-research ecological chain in China and even in the world [14]. Its mixed social entrepreneurship model of "public welfare aided learning + employment + entrepreneurship industry-university-research and public welfare integration" has been recognized by domestic and international academic circles and national leaders, and has benefited tens of thousands of teachers and students in colleges and universities. Therefore, combined with the experience of famous universities at home and abroad in cultivating college students' social enterprises and social entrepreneurship, the author puts forward the following suggestions:

\section{A. Establishing research's platforms related to social innovation and social enterprises}

To cultivate college students' social entrepreneurship, it is necessary to establish a research platform related to social innovation and social enterprises in colleges and universities. Universities should take the establishment of social innovation and social enterprise research platform as the inheritance and core of teaching. The establishment of a research platform can not only promote social innovation and research in social enterprises. In addition, more relevant full-time and part-time teaching staff can be involved in the investigation and study of "social enterprises" to learn, which is helpful to the improvement of teaching. Taking Hunan University as an example, Hunan University has established the China Public Welfare Entrepreneurship Research Center under the guidance of the Ministry of Education, which is headed by the university leaders. The research team is composed of academicians, professors, associate professors and doctoral students. At the same time, an "academic advisory committee, a leading group on social entrepreneurship education for college students" composed of principals and academicians, and experts from the Ministry of Education and well-known domestic scholars have been set up. At present, Hunan University ranks first in the world in the research of social innovation and social enterprises, and its research platform offers a solid theoretical basis for the cultivation of "social entrepreneurs". The scientific research of colleges and universities can refer to the relatively perfect scientific research system of Hunan University, set up research platforms and carry out relevant research of social enterprises according to their own advantages and characteristics.

\section{B. Constructing the course teaching system of social enterprise and social entrepreneurship education}

The cultivation of social entrepreneurship focuses on guiding college students to pay attention to social problems worldwide. They are good at discovering social problems from increasingly complex societies, cultivating college students' ideas of participating in social enterprises, and addressing social problems with their professional expertise. Therefore, the cultivation of social entrepreneurship must be integrated into the whole process of higher education. Firstly, introduce the courses about social enterprises, such as introduction to 
Public Welfare Entrepreneurship, Public Welfare Entrepreneurship (Social Entrepreneurship), Social Entrepreneurship, etc. Secondly, in the professional courses, entrepreneurship courses and ideological and political courses of college students, the teaching and education about "social enterprises" and typical characters of social entrepreneurs should be integrated. Social entrepreneurship enables college students to learn more, and their sense of social responsibility and mission are stimulated, which lays a good theoretical foundation for the comprehensive education of social entrepreneurship college students and the cultivation of future social entrepreneurs.

\section{Establishing the practical teaching system for college students to establish various social enterprises}

The practice of re-entering social enterprises through the theoretical study is the transformation of college students from "quasi-social entrepreneurs" to "real social entrepreneurs". Colleges and universities can set up professional guidance institutions, such as "Guidance Center for the Development of College Students' Social Enterprises and Social Entrepreneurs". The responsibility of this organization is to organize and guide college students to participate in social enterprises, and regularly lead the organization of "public welfare entrepreneurship" competitions on campus or in the region. The second is to guide students to actively participate in various national social entrepreneurship competitions, such as the Youth Creation Public Welfare Entrepreneurship Competition of the League Central Committee, the China Youth Volunteer Public Welfare Entrepreneurship Competition, the KAB Youth Henghao Public Welfare Entrepreneurship Competition, and the Ministry of Education's Internet + Public Welfare Entrepreneurship Competition. Thirdly, professional incubators of "social entrepreneurship" and venture capital funds of social enterprises should be set up in schools or in conjunction with local government departments. It can guide students to carry out social entrepreneurship and register various social enterprises for various social practices, open up the links between government and venture capital, and help and support the landing of social enterprises set up by university students. The incubation of social enterprises will stimulate the enthusiasm of college students to set up social enterprises.

Through the establishment of research platform, teaching system and practice system of "social innovation and social enterprise", colleges and universities have formed a "trinity" mode of social entrepreneurship education for university students in industry, university and research based on the premise of safeguarding "public interests". This will surely promote higher education in China to cultivate more societies capable of breaking the new era. In the course of development, more new and compound talents will be trained and they will address the problems of "unbalanced and inadequate", and then they will safeguard the healthy development of social fairness and justice.

\section{CONCLUSION}

First, this paper analyzes the definition and relationship of social enterprise, social entrepreneur and social entrepreneurship. Then analyzes the necessity and the ways of cultivating college students with social entrepreneurship. The conclusions are as follows: Social entrepreneurship is a talent that can integrate social and economic benefits. It is necessary to cultivate college students with social entrepreneurship in the new era because social entrepreneurship can reshape the social morality of college students, promote the innovative thinking of college students in the new era, and cultivate their consciousness of "sustainable development economy". The measures to cultivate college students' social entrepreneurship include setting up research platforms related to social innovation and social enterprises, constructing a curriculum teaching system of social enterprises and social entrepreneurship education, and establishing a practical teaching system for college students to set up various kinds of social enterprises.

\section{REFERENCES}

[1] Nyssens, Marthe(ed), Social Enterprise, New York: Routledge, 2006, pp 3-4. $\square$

[2] Wang Ming. Social Enterprise: Connotation, Domestic Practice and Extraterritorial Experience [J]. Party and Government Cadre Journal, 2019(3): 70-75. (In Chinese)

[3] Yuan Feng. Public Welfare Entrepreneurship Promotes Cross-border Integration-New Changes in Social Innovation and Development [J]. China Collective Economy, 2018(04): 46-47. (In Chinese)

[4] Tang Yayang, Wang Zhong, et al. Introduction to Public Welfare Entrepreneurship [M]. Changsha: Hunan University Press, 2009: 167. (In Chinese)

[5] Xu Yongguang. Public Welfare to the Right and Business to the Left [M]. Beijing: CITIC Publishing Group, 2017: 2. (In Chinese)

[6] The Opportunity, Experience and System Improvement of Social Enterprises to Participate in Precision Poverty Alleviation-Based on the Case Study of Chengdu N Agricultural Development Company [J]. Social Policy Research, 2019, 21(1): 73-81. (In Chinese)

[7] $\mathrm{Xu}$ Xiaozhou, Ni Hao. The Development Trend and Strategy of Social Entrepreneurship Education [J]. Higher Education Research, 2017(2): 38-44. (In Chinese)

[8] Tian Rong. Mission vs. Life: The Balance of Social Enterprise Double Targets in the Yangtze River Delta Region [J]. China's Third Sector Research, 2018(16): 100-124. (In Chinese)

[9] Feiss, Chip. "Social Enterprise-The Fledgling Fourth Sector", Financial Times, 2009-07-28(11).

[10] Liu Zhiyang, Li Bin, Chen Hewu. Research on Social Entrepreneurship Based on the Entrepreneurship [J]. Management World, 2018(11): 171-173. (In Chinese)

[11] Du Juan. The Balance of Social Enterprises [J]. Observation, 2019 (1): 54-55. (In Chinese)

[12] Wang Tianfu, et al. Good Money can Also Drive Out Bad Coins: New Enlightenment of Social Enterprises on the Circulation Economy [J]. China's Circulation Economy, 2018 (11): 13-21. (In Chinese)

[13] Lin Hai, Peng Jinsong, Yan Zhonghua. Research on Transformation Strategy from NPO to Social Enterprise-Non-profit Organization [J]. Science and Technology Management Research, 2010(18): 215-218. (In Chinese)

[14] Jacques Divni, Ding Kaijie, Xu Tianxiang. From the Third Sector to Social Enterprises: Concepts and Methods [J]. Economic and Social System Comparison, 2009 (4): 112-120. (In Chinese) 